\title{
Teeling Whiskey Company: A Tradition of Family Entrepreneurship and Whiskey Distilling
}

\section{August, 2015}

Abstract: This case explores the origins of a new high-growth, family start-up competing in a traditional industry. Teeling Whiskey Company Ltd (TWC) is the brainchild of entrepreneur Jack Teeling. This new venture stems from another high-profile, family based business named Cooley Distillery. Jack was managing director of Cooley Distillery, the business his father founded in 1987. In Cooley Distillery, Jack acquired a wealth of professional experience in whiskey distilling and selling. When the distillery was sold to a large US spirits company in 2012, Jack pursued his own entrepreneurial venture in Irish whiskey. A year after the business was founded, Jack was joined by his brother Stephen Teeling and together they have shaped their idea for a boutique, premium whiskey distiller producing innovative offerings, into a fast growing, internationalized business. Jack and Stephen need to build a niche for TWC, as many new distilleries are due to enter the market.

Keywords: entrepreneurship; prior knowledge; prior experience; start-up; family business Key learning outcomes: perceiving opportunities; pre-incubated start-ups; examining the 'nature vs nurture' debate 


\section{The Teeling Family in the Whiskey Industry}

Jack Teeling was sitting in a labour ward awaiting the birth of his daughter when he received an email informing him that the sale of the whiskey company he managed was to proceed. In Jack's mind, two momentous occasions had occurred: firstly, the birth of his daughter and secondly, his decision to leave the newly acquired distillery and establish his own whiskey business.

Jack Teeling was managing director of Cooley Distillery when the sale was negotiated. The board of Cooley agreed to the sale of the distillery to Beam Inc., a multinational business, (now Beam Suntory) for $\$ 95$ million ( $€ 71$ million). Despite having 350 shareholders, Cooley was considered a family affair as almost half of the company's shares were owned by Teeling family. Jack's father, John Teeling, founded Cooley in 1987 and developed it over the following 25 years. Jack and his younger brother, Stephen, worked in Cooley for ten and seven years respectively and rose to senior management positions: Jack to managing director and Stephen to global retail manager. Both brothers acquired shares in the company. For the Teelings, the sale was more than the loss of company control — it was the loss of a legacy.

Many past offers for Cooley were rejected, so Jack was shocked to realize that this time, the deal had materialized. Following a decade at Cooley, Jack possessed a good understanding of whiskey distilling processes, but his strength lay with whiskey sales and marketing. In Jack's view, establishing his own whiskey company was the next logical step:

'I could have gone off and got a franchise or could have got involved in property, investing or financial services but I felt I had a specific insight into Irish whiskey therefore, it would be foolish of me not to utilize that knowledge and those 
connections and relationships and see if I could actually carry on what we had started in Cooley.'

Jack was aware that whiskey distilling was risky. The payback period is lengthy as attested by Cooley Distillery, which took 11 years to make its first profit and 15 years before cumulative profits exceeded cumulative losses. However, Jack believed Irish whiskey presented a potentially rewarding opportunity and this drove his passion for re-entering the whiskey industry:

'I wanted to get right back in there and fill that hole in the market that was being created, be it with a range of products that international distributors would have or spark the consumers' interest in different things from Irish whiskey. I think we've managed to take advantage of that quite successfully over the last two to three years.'

Teeling Whiskey Company (TWC) is an internationalized start-up with the ambition to reinvigorate the Irish whiskey category. Jack's vision is to grow the business from whiskey blending and bottling to distilling. Joined by Stephen in 2013, the brothers have led the company to rapid growth, with international turnover increasing from $€ 143,500$ to $€ 1.8$ million in a year.

In 2012, as TWC formed, the Irish whiskey category experienced a major revival. The sector is expected to invest $€ 1$ billion in Ireland over the next decade as Irish whiskey exports are set to double to 12 million cases by 2020 . In the face of emerging competition, Jack has shown a steely resolve and unwavering ambition in his attempt to offer a fresh take on Irish whiskey: 
'We don't want to just produce an Irish whiskey. We want to produce the most interesting, different Irish whiskey so that when people want to get away from the mass market they can discover us and we can take them on a journey of trying different things.'

This is the story of entrepreneur Jack Teeling and the origins of his whiskey start-up, TWC. The aim of this case is to challenge the preconceived notion of entrepreneurs as solo entities and instead, consider entrepreneurs as 'organizational products' drawing on existing organizational experiences and resources for entrepreneurial opportunities (Freeman, 1986). The case explores Jack's early life, his Cooley Distillery career, the establishment of TWC and TWC's initial growth.

\section{Jack Teeling, the Entrepreneur}

As children, Jack (see Figure 1) and Stephen Teeling became accustomed to the business world. Jack describes himself as an independent person who never liked asking for help, even in childhood. Their father, John Teeling was an established entrepreneur with stakes in multiple natural resource companies. John Teeling, once a lecturer of business in a leading Irish university, founded Cooley Distillery in 1987, when Jack and Stephen were aged eleven and six.

Business appealed to Jack and in 1994, he attained a Bachelor of Commerce degree at University College Dublin. Following this, he completed a Master's degree in Finance. Jack worked as a private bank equity dealer for three years before joining his father's whiskey business in 2002. He began his Cooley career in a commercial role before moving to sales 
and marketing director in 2007. Jack also completed a part time Master's degree in International Marketing so he could give the company added value. On his progression in Cooley, Jack remarks:

'I became managing director in 2010 and started big change, managing programmes, trying to evolve the organization to allow us to take advantage of the opportunities. We were really beginning to see the benefits of what we were doing.'

Jack implemented a revised corporate strategy for Cooley that focused on launching super and ultra premium products, targeting four key brands at established European and US whiskey markets, and expanding the marketing team. While developing Cooley's strategy, Jack gained vast insight into consumer trends within the whiskey industry:

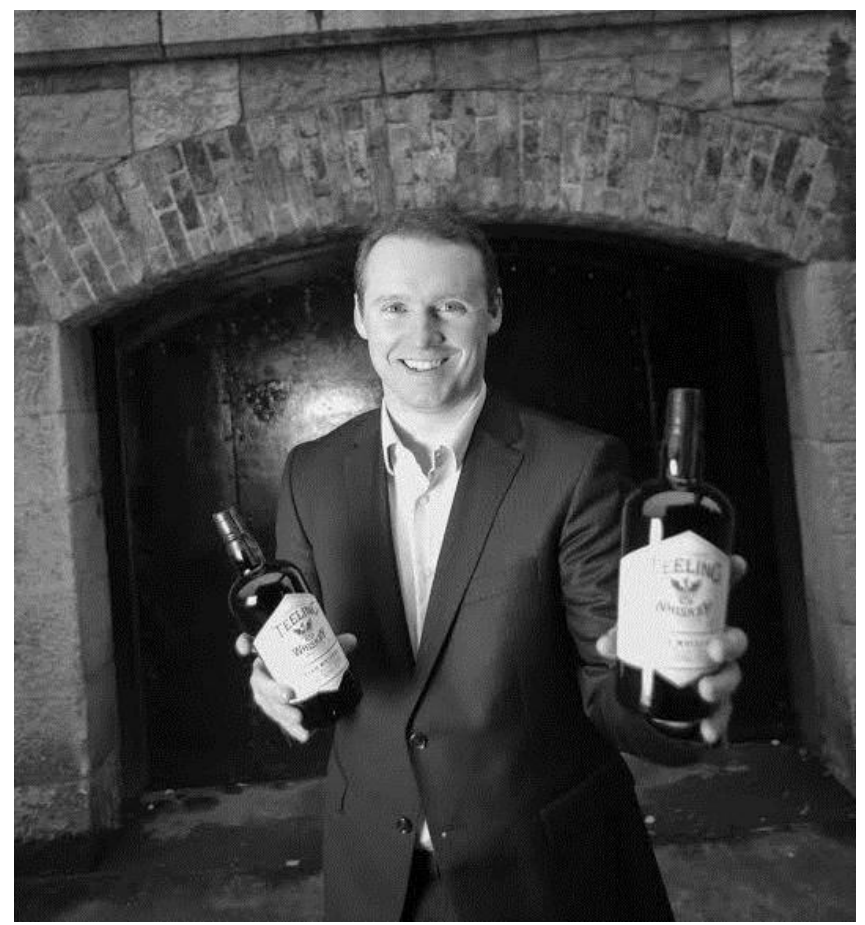

Jack Teeling 
'What I noticed in Cooley was that the world changed quite dramatically for Irish whiskey from the 1990 's up to 2005/2006. Millennial consumers were coming into the category. It was really hard for Cooley to adapt because it had been set up in a certain way. It had scar tissue from the tough years in the 1990's. There was a big selling job for someone like me to go in and drive a huge amount of change at the top level.'

His brother, Stephen, was appointed a marketing role when he joined Cooley in 2006. Post Cooley sale, Stephen stayed with Cooley and was promoted to senior global marketing manager for Irish whiskey. Jack was given the opportunity to stay at Cooley but he declined the offer. As managing director, Jack was afforded a high degree of self-autonomy, which he believed would not be maintained under the management of a multinational company. Jack had mixed feelings about his departure from Cooley:

'It was a family company but it wasn't my vision. It always had to be respectful to the people that were there before. For me there was a bit of mourning when Cooley was sold but it did provide a blank canvas for what I thought was required for a new premium Irish whiskey.'

He oversaw the integration process of Cooley into Beam before pursuing his own entrepreneurial venture. Jack believes his inherent risk-taking ability stems from exposure to his professional environments. Yet, he is a proponent of both 'nature and nurture' in explaining entrepreneurial tendency. In April 2012, three months following the sale of Cooley, Jack established TWC (see Figure 2). 
Figure 2. Timeline of key events and evolution of Jack Teeling's professional life.

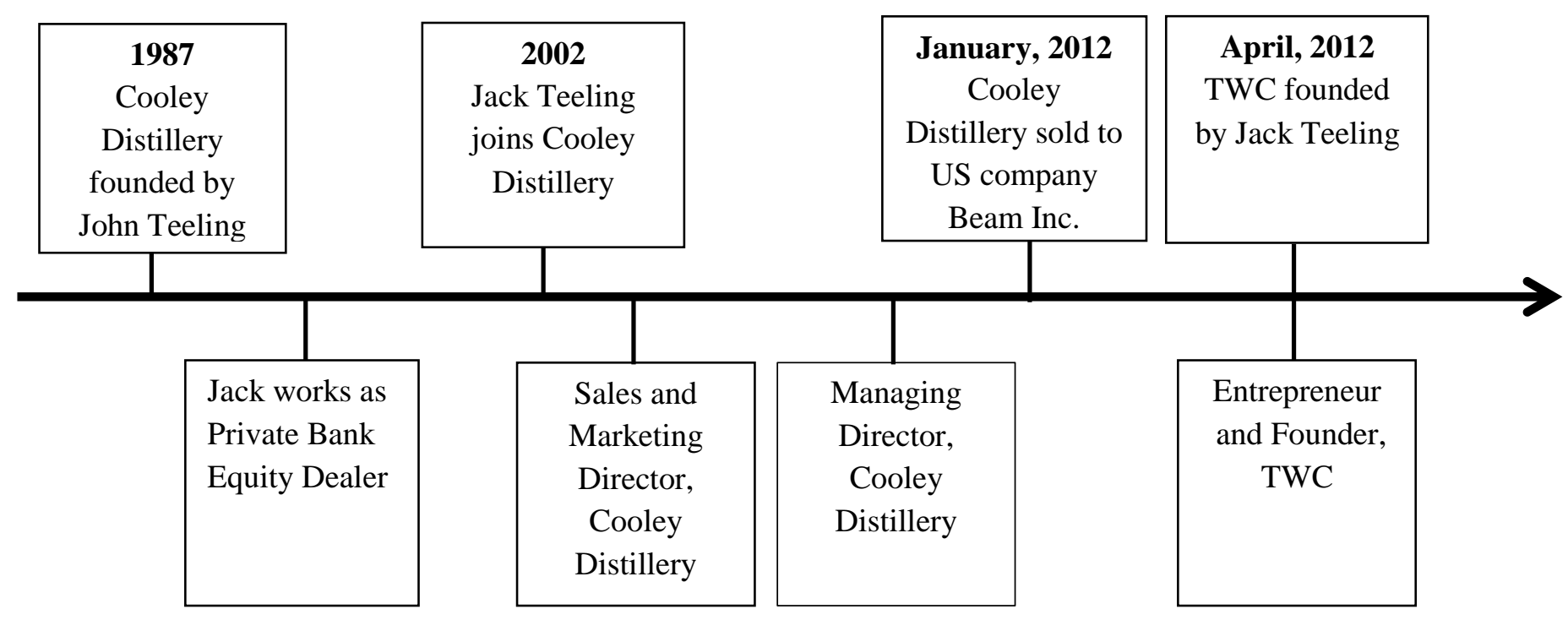

\section{The Start-up of Teeling Whiskey Company}

Jack and Stephen used their pay-outs from Cooley to fast track TWC. In 2012, company shares totalling $€ 1.3$ million were sold to Teeling family members with share ownership split between the following people: Jack (43\%), Stephen (37\%), their parents, John and Deirdre (7\% each), and their sister, Emma (6\%). TWC is a self-funded entity aside from asset based loans for inventory. The finance enabled Jack to begin company operations before producing even a drop of Teeling whiskey.

Getting TWC operating required one major resource: a ready-made product. Jack and Stephen brokered a deal to purchase enough Cooley stock (16,000 barrels) from Beam Inc. to keep TWC operational until own-production commenced. 'That (whiskey stock) has proven to be a critical element in having a tangible product, driving revenue for the company and helping us fund what we're doing now', said Jack. 
TWC whiskey is custom blended and matured in hand selected wooden casks. The TWC warehouse or maturation facility is based in the Cooley Peninsula, County Louth, Ireland. Jack recognizes the unusual nature of his resource attainment:

'We're doing it backwards. We have whiskey now and we're exporting to 30 different markets. We have a reasonable brand awareness with people and we're going to continue to build on that until production in Dublin comes on stream and then we can plug into that network and our products that we've already created.'

From the start, Jack was managing director, his wife Katherine was made company secretary and Alex Chasko was appointed as TWC's master blender and distiller. Cooley's former innovation manager, Alex, has a background in micro brewing from Portland, Oregon. He attained a Bachelor of Science degree in Chemistry at University of Oregon and a Master's degree in Brewing and Distilling at Heriot-Watt University, Scotland. Jack needed someone who shared his vision yet delivered the technical expertize required:

'He was involved in installing the micro distillery in Kilbeggan (part of Cooley). I kept in touch with him once I was on the way out and knew what I was doing and he became our first employee in June after I left.'

In May 2013, the TWC team expanded when Stephen left Beam Inc. and joined the business as sales and marketing director. 


\section{TWC's First Steps}

A distillery is central to the company's progression from whiskey blending and bottling to producing. Jack's idea to build a distillery and on-site visitor centre emerged when the Kilbeggan micro distillery, as part of Cooley, was under construction. Jack knew that a distillery would secure TWC's future whiskey supply while enabling them to create a unique, innovative Irish whiskey portfolio using the traditional Dublin style of distillation. The pot distillery consists of three traditional copper pot stills with the capacity to produce 500,000 litres of whiskey annually.

At Cooley, Jack became aware of the huge market potential in Irish whiskey when he noticed an international revival in urban distilling. He remarked: 'I was looking at what was happening in Brooklyn and London and to me there was a massive gap to do it in Dublin.' In the 1970's, two Irish whiskey powerhouses, Jameson and Powers, moved their operations outside of Dublin, bringing Dublin whiskey distilling to an end. TWC claimed the title of 'first new distillery in Dublin for over 125 years' which sparked attention from national media. With a strong family heritage - a Teeling relation established a distillery in 1800's Dublin - and a clever slogan, 'The Spirit of Dublin', TWC has a brand rich in personality.

However, every opportunity presents substantial risks, and at 36 years old with a young family, Jack had to take careful consideration. The distillery and visitor centre required a $€ 10$ million investment. In accordance with the Irish Whiskey Act, 1980, spirits must be matured in wooden casks for no less than three years making the first batch of own distilled Teeling whiskey ready for sale in 2018. Jack was not deterred and building commenced in August, 2014. However, he soon realised the difficulty of building a distillery, operating an existing business and managing cash flow concurrently. 'Probably the most difficult thing has just been paying the bills as they fall due', said Jack (Bodkin, 2015). 
As construction of the distillery progressed, TWC continued blending and bottling whiskey. Their current products include the flagship Teeling Small Batch, Teeling Single Grain, Teeling Single Malt, and Teeling Premium Poitin ${ }^{1}$. Sales of existing stock are crucial to sustaining cash flow and funding the build. The key challenge for TWC is to ensure their limited stock sells at the right price and doesn't run dry until production comes on stream. However, Jack's ambitious construction plan in one of the most expensive city locations has limited the funding available to spend on advertising. To generate widespread publicity cheaply, the team focused efforts on social media channels (Twitter, Facebook and video sharing site, Vimeo), disseminated press releases to the national media, and promoted products at events such as Whiskey Live Dublin.

\section{TWC-A Young Player in a Mature Market}

As a new entrant in a traditional industry, TWC must stand apart from established competitors. In essence, Jack's start-up strategy for TWC focuses on three key elements: innovation, whiskey market segmentation and internationalization.

Innovation is a top priority for the TWC team. The TWC bottle label features a phoenix, a symbol of regeneration and unique remarkability (see Figure 3). This mythical creature aptly reflects the company's bold mission statement:

'While being respectful to the past and our own provenance we are confident enough to forge a new future for Dublin and Irish whiskey through innovation and daring to do things differently.'

Alex Chasko leads the introduction of innovative and flavoursome whiskey expressions. While product experimentation was limited to blending and maturation, TWC produced 
award-winning expressions including the Teeling Single Grain whiskey, matured in Californian red wine barrels. In February 2013, TWC debuted Teeling Small Batch Irish whiskey, which later became their flagship product. This small batch blended whiskey, made of malt and grain whiskey matured in rum casks, is TWC's innovation. Jack's idea for whiskey maturation in rum barrels was inspired by Cooley. The blend is then bottled at $46 \%$ with no chill filtration which locks in greater flavour. Jack and his team conducted consumer tastings and $90 \%$ of participants preferred the rum married blend, reaffirming their confidence in the product.

Since its launch, the whiskey has been awarded numerous accolades including Best Drinks Launch of the Year 2013 at the Drinks International Travel Retail Awards and Gold Medal at the 2013 Spirits Masters. In October 2014, the company released its latest offering, a 23 year old single malt matured in five different wine casks. This cask maturation technique is new to Irish whiskey, making it possibly the most innovative TWC bottling yet.

Figure 3. Teeling Whiskey Company Logo.

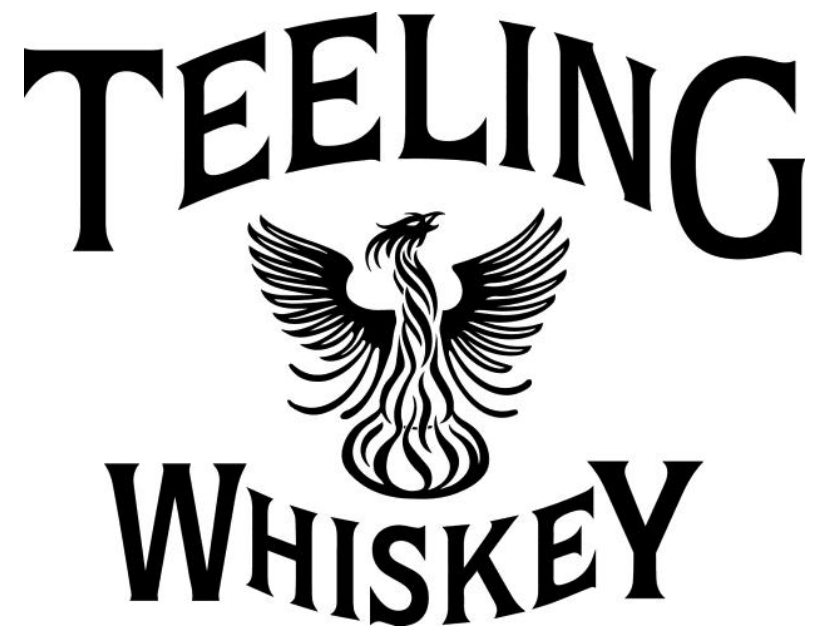

Source: whiskyexperts.net 
In Jack's view the Irish whiskey category is at the beginnings of segmentation. Carving a niche as a boutique, premium whiskey distiller is central to the TWC business strategy, according to Jack:

'We've gone after areas we feel are very under developed in Irish whiskey so again you're not competing with the 'big boys'. It's about creating your own niche and unique offerings that will allow you to maintain your price positioning and don't get caught up in the noise that the multinational can generate.'

TWC's product portfolio includes a collection of premium single malt, single grain and blended whiskies. This range of whiskies targets a large consumer grouping from the novice spirits drinker to the whiskey connoisseur. At the higher end is the vintage reserve collection 7of Irish single malts ranging in maturation periods of 21, 26 and 30 years. Teeling's 30 year old Single Malt retails at $€ 1,500$. Jack found that the $€ 30-€ 50$ price range for Irish whiskey was unchartered territory so he exploited that price point gap by positioning a range of premium whiskies at around $€ 35$. Jack’s intention was to provide an easy and affordable trade up solution from the standard Irish whiskies retailing at $€ 25$. The moderately priced and sweet tasting Teeling Small Batch retails at €39.99 making it an affordable option for cocktail consumption. Jack and Stephen focused on the 'mixology' trend within the alcohol industry which led to a range of Teeling whiskey cocktails. Stocked in Dublin City's trendiest cocktail bars, TWC exudes a young, exciting, and urban vibe.

With Irish whiskey reportedly the fastest growing spirits category globally, it was an opportune time for internationalizing TWC. Global sales of Irish whiskey grew from 1.5 million cases annually to 6.2 million cases annually over 15 years (as of 2014). Jack became aware of America's growing craft liquor movement and spotted an opening for TWC. In April 2014, TWC launched whiskey in approximately 17 American states via an importer, 
'Infinium Spirits'. TWC's ambition for the US whiskey market is to introduce gradually a more expensive selection of whiskies. Jack explained this strategic market position:

'The standard brands in the Irish whiskey category are in the \$20-\$30 range. Higher up you have whiskies like Redbreast and the Bushmills malts, but there's not much in the middle. We want to provide a stepping stone and educate American palates, because Irish whiskey has more to offer than what they might expect.' (Shanken News Daily, 2014)

While market conditions are favourable for craft distilleries like TWC, there remains competition from bigger, well-established players. Jameson, the best-selling Irish whiskey, continues to lead with growth of $13 \%$ in the nine months to March 2014 due to strong US demand. As a small company, however, TWC has performed impressively. TWC's exports have exceeded home sales resulting from the brothers' internationalization strategy. Jack's access to international distributors at Cooley was used to secure importers in the UK, France, Germany, Russia, Canada, Belgium, and more, for TWC. Their pursuit of existing and emerging whiskey markets has resulted in TWC's presence in 35 export markets. Jack accredits Cooley for enabling them to internationalize quickly: 'We're lucky to build upon our credibility that we established in our Cooley days.'

\section{Teeling Whiskey Company_An Entrepreneurial Success?}

TWC has entered the marketplace at an exciting, yet increasingly competitive time with plans for up to 20 new distilleries across Ireland. This includes Dublin Whiskey Company and Alltech, both of which plan to build distilleries in Dublin City with the former set to open two doors away from TWC. Jack and his team must fund whiskey production with sales of 
existing stock. This is a long term cash flow challenge that Jack hopes to alleviate with revenue generated from their visitor centre. In June 2015, both distillery and visitor centre opened with a team of 30 full time staff. The state of the art distillery affords Alex Chasko more freedom to experiment with whiskey flavourings. Jack anticipates that the visitor centre (complete with café, display and tasting rooms) will attract some 50,000 visitors a year, which he hopes to double annually over time.

Jack and TWC have had some notable achievements to date. Jack Teeling is the first person to open a new distillery in Dublin for over 125 years. The TWC team has won over 40 awards for their whiskies, launched a range of innovative products, and constructed a distillery and visitor centre in Dublin's heartland. Within a year of trading, TWC reported a profit after tax of $€ 74,000$ from revenues of $€ 2.7$ million. Irish sales jumped dramatically from $€ 9,500$ in 2012 to $€ 907,000$ in 2013. Even more impressive was overseas revenues which grew by $€ 1.6$ million within a year ( $€ 143,500$ to $€ 1.8$ million). TWC reported that $32 \%$ of sales were European and $34 \%$ were worldwide.

In 2014, TWC was one of ten competitors worldwide shortlisted for the 'Overall Boutique Distiller of the Year' award at the International Wine \& Spirit Competition. Teeling Single Grain whiskey and Teeling 21 year old Single Malt whiskey were awarded World's Best in their respective categories at the World Whiskies Awards 2014. Speaking about this success, Jack Teeling remarked:

'We are very proud of the whiskeys we have launched over the last two years and we are humbled to receive such recognition at one of the biggest awards in the whiskey world. These awards give us confidence to continue to launch innovative expressions of Irish whiskey driving choice within the Irish whiskey category.' (Teeling Whiskey Company, 2014) 
Jack admits he doesn't stop to celebrate achievement. He is focused on directing TWC forward and ensuring continued success. Jack remarks: 'We've come a long way but we've so much more to go. Let's keep going.' It runs counter to Jack's forward thinking approach, but nonetheless the questions should be asked: What drove Jack to pursue this high risk venture? How have Jack and the team created this new business, which already includes an international whiskey brand, within three years of start-up? 


\section{Teaching Note}

\section{Case Synopsis}

This case study examines the origins of Jack Teeling's new whiskey start-up, the Teeling Whiskey Company (TWC). Following the sale of his father's whiskey distillery (Cooley Distillery) to a large US company (Beam Inc.), Jack founded TWC in 2012. TWC is a boutique family-owned business run by Jack, his brother, Stephen, and master distiller, Alex Chasko. All three worked in Cooley Distillery where they accumulated extensive knowledge and experience of whiskey distilling and selling.

TWC was funded by proceeds of the Cooley sale, its whiskey stock was acquired from Cooley, and Jack used his contacts from Cooley to establish international routes to market. The start-up occurred in the context of accelerating global sales in the Irish whiskey category, reported to be the fastest growing drinks spirit in the world (sales have grown from 1.5 million cases annually to 6.2 million cases annually over the past 15 years-2014). In light of this opportunity, there are plans for up to 20 Irish whiskey distilleries to open nationwide in the coming years. Jack has sought to differentiate his offering to the Irish whiskey category through product innovation.

While only in its third year of operations, TWC has made impressive revenues to date, most of which are from international sales. What drove Jack to pursue this high risk venture? How have Jack and the team created this new business, which already includes an international whiskey brand, within three years of start-up? 


\section{Learning Outcomes}

The key objectives of this case study are to:

- Illustrate how social, contextual, and organizational factors help explain the origins of new ventures. More specifically, the case allows students to explore if entrepreneurs are organizational products rather than purely independent, solo entities (Freeman, 1986).

- Ignite discussion surrounding the 'nature versus nurture' debate in entrepreneurship.

- Emphasize the importance of prior knowledge in opportunity recognition (Shane, 2000).

- Consider how family involvement in a business shapes entrepreneurial action.

\section{Discussion Questions}

(1) Using the Timmons Model of the Entrepreneurial Process (Spinelli and Adams, 2012) identify the factors that led to Jack and his team creating this international, fast growing venture?

(2) Identify the prior knowledge and experience that influenced Jack's perception of opportunities in the world whiskey market.

(3) Is TWC a typical start-up?

(4) Based on this case, would you involve your family in your new start-up?

(5) Is it 'nature or nurture' that explains Jack's entrepreneurial activity? 


\section{Case Analysis}

(1) Using the Timmons Model of the Entrepreneurial Process (Spinelli and Adams, 2012) identify the factors that led to Jack and his team creating this international, fast growing venture?

TWC's fast track to success is explained by the combined impact of both internal and external forces upon the company. Students should take into consideration TWC's preincubated nature; that is, a venture with a product set for market, a business plan, and a legally constituted company prior to operations. Drawing on the Timmons Model of the Entrepreneurial Process (Spinelli and Adams, 2012) we can apply the three factors central to a successful venture ((i) opportunity evaluation, (ii) resource assembly, and (iii) team creation) to the TWC case study. Jack identified four key factors to TWC's success: developing consumer insight, a changing industry, efficient resource assembly, and utilizing Cooley connections.

\section{(i) Opportunity Evaluation.}

It is the role of the entrepreneur to determine the potential of an opportunity and, based upon this evaluation, the amount of time and effort spent exploiting it (Spinelli and Adams, 2012). Jack surveyed the market trends both in Irish whiskey and in other spirit categories. He developed good consumer insight during his time at Cooley where he noticed an increase in millennials consuming Irish whiskey. One of TWC's main consumer groups is millennials (the 21-35 year old demographic).

Jack also noticed a revival of urban whiskey distilling in locations such as Brooklyn and London. He noticed the lack of craft distilleries in Dublin which provided him with an unexploited gap in the marketplace. 
The Timmons model advocates using the least amount of required resources, a process referred to as bootstrapping. Accomplished entrepreneurs adopt 'ingeniously creative and stingy strategies' for resource attainment and usage (Spinelli and Adams, 2012). Jack applied this bootstrapping mentality when acquiring resources for TWC. The purchasing of whiskey stock from Beam Inc. was a prerequisite to TWC's trading operations. Jack remarked: 'That (whiskey stock) has proven to be a critical element in having a tangible product, driving revenue for the company and helping us fund what we're doing now.'

Other forms of efficient resource gathering involved seeking investment from family members, maintaining a small team sufficient for initial growth, and utilizing a warehouse in Cooley as a maturation facility. Jack dealt with many international distributors during his time as managing director of Cooley. He was able to utilize his contacts to provide TWC with routes to foreign markets and build the company's exports.

\section{(iii) Team Creation.}

An entrepreneurial team is central to a business striving for accomplishment, according to the Timmons model. Jack has a proficient management team at TWC. Jack and Stephen Teeling and Alex Chasko have extensive knowledge of distilling and selling whiskey. Access to industry professionals is essential for any business. For TWC, Jack drew upon a valuable network he developed during his time at Cooley. One example of networking was the recruitment of Alex Chasko who worked at Cooley Distillery where he led projects in innovation. The TWC management team will need to implement effective delegation and leadership skills once team expansion occurs. Accordingly, the role of the entrepreneur as 'a pacesetter and culture creator' is essential to the team's development (Spinelli and Adams, 
2012). To date, Jack has shown clear vision and a drive for future business growth while referring to TWC's success in collective terms.

Recommended reading:

Spinelli, S., and Adams, R. (2012), New Venture Creation-Entrepreneurship for the 21st Century ( $9^{\text {th }}$ ed.) McGraw-Hill/Irwin, New York.

(2) Identify the prior knowledge and experience that influenced Jack's perception of opportunities in the world whiskey market.

When answering this question, students should review key milestones in Jack's life which led to TWC's establishment. It may be of help to number these events in order of relevance to Jack's opportunity perception. The influence of Jack's father, the establishment of Cooley, Jack's academic qualifications, his varied professional roles, and his movement through the ranks in Cooley were all important factors in the set-up of TWC. In addition to knowledge and experience, Jack's education and multiple professions provided him with the selfconfidence and motivation to pursue his own entrepreneurial endeavour.

Shane (2000) claims that there are three forms of prior knowledge conducive to the discovery of an entrepreneurial opportunity: prior knowledge of markets, prior knowledge of ways to serve markets, and prior knowledge of customer problems. The TWC team have a strong grasp of the first two types of knowledge.

When in Cooley, Jack developed an expansive knowledge of the whiskey market. He became aware of an international revival in urban distilling which led him to notice an unexploited market opportunity for an Irish whiskey marketed as a 'Dublin' whiskey. Jack also noticed the increased interest in craft distilleries and the beginnings of market segmentation within the Irish whiskey industry. Jack knew his company could not compete 
with the large scale operations of big competitors, so he focused on segmenting the market. This strategy is similar to Pelcor - a traditional cork production company in the south of Portugal - that targeted specific consumer groupings so as to differentiate itself from the large international fashion brands (Carvalho and Williams, 2014).

The TWC team has a comprehensive knowledge of ways to serve markets. On the marketing side, Jack and Stephen have expertise in business management, sales and marketing, global marketing and finance. Alex Chasko's skillset ranges from whiskey distilling operations to product innovation. As a prior managing director of a public limited company, Jack is accustomed to a leadership and managerial role. Stephen was global retail manager at Cooley and then senior global brand manager for Irish whiskey at Beam Inc. TWC's Chief Technical Officer, Alex Chasko, was a manager at Cooley Distillery where he oversaw projects and innovation at two distilleries.

Jack possesses an understanding of the issues within the Irish whiskey industry such as the lack of choice, innovative flavourings, and premium whiskey offerings set at the $€ 30$ €50 price range. Jack's well-developed perspicacity stems from over a decade of prior experience in the industry. Therefore, the knowledge Jack gained at Cooley was invaluable to perceiving opportunities within the world whiskey market.

\section{(3) Is TWC a typical start-up?}

TWC's start-up model is unusual in various ways.

Firstly, TWC is what is described as pre-incubated or 'ready to be developed'. The idea of starting a business at a kitchen table with an independent resource assemblage is a notion that's not realistic for many entrepreneurs, as Freeman (1986) states: 'entrepreneurs often are organizational products'. To get off the ground, TWC needed significant seed capital and most importantly a product for the market. Since whiskey requires at least three 
years to mature there was no ready-made TWC whiskey for sale. Jack Teeling brokered a deal with Beam Inc. to purchase 16,000 barrels of aged Cooley whiskey. The start-up was funded by the share of the Cooley sale allocated to Jack and Stephen and by family members who bought company shares.

Secondly, the company is characteristic of a 'born global firm' with a growth trajectory that has been primarily export driven. At the end of their second year of trading, international turnover doubled domestic turnover. Jack had access to international distributors from Cooley which provided a route to multiple export markets.

Thirdly, TWC is a family affair, which presents unique opportunities and challenges for the business.

\section{(4) Based on this case, would you involve your family in your new start-up?}

When answering this question, students should give consideration to both the merits and drawbacks of family involvement in a business. There are significant advantages to being a family-centred business.

Family involvement in business can activate entrepreneurial thought and action. Jack's time in his father's business, inspired him to look at the whiskey market for business opportunities. The sale of Cooley was further motivation for Jack to pursue his own venture.

Family involvement was of major financial support to Jack establishing TWC. In 2012, company shares worth $€ 1.3$ million were bought by Jack, Stephen, their parents, and their sister. In addition to financial backing, family members may also provide emotional support to those in pursuit of entrepreneurial opportunities.

Another advantage is the usage of family branding, which is particularly beneficial when marketing a heritage product. The Teeling family tradition of whiskey distilling affords 
the company a degree of authenticity and proficiency, more so, than a company with no associated whiskey experience.

Involving family in your business can cause difficulties to arise. Tension can emerge when major business decisions take effect. For example, John Teeling, Jack's father, has stated that his sons were very upset at the sale of Cooley Distillery. The continuation of family values can be both a hindrance and benefit to company growth. In the case of TWC, the brothers acknowledge the 'family tradition of quality over quantity'. They remain respectful to their own provenance while adopting new, bold techniques. In Cooley, Jack was limited:

'It was a family company but it wasn't my vision. It always had to be respectful to the people that were there before. For me there was a bit of mourning when Cooley was sold but it did provide a blank canvas for what I thought was required for a new premium Irish whiskey.'

In the future, share ownership dilution may occur as shares are divided among offspring or nieces and nephews of Jack and Stephen. It should be noted that TWC is in the early stages of development and as of yet, the main family business issues (succession, governance structures, wealth transferal) may not have emerged.

\section{(5) Is it 'nature or nurture' that explains Jack's entrepreneurial activity?}

Students can be asked to consider if Jack's recognition of an entrepreneurial opportunity was as a result of special attributes such as an innate, heightened perspicacity (Schumpeter, 1934; Shackle, 1979) or of prior knowledge (Fiet, 1996; Shane, 2000; Venkataraman, 1997). Was Jack born an entrepreneur or does the story of TWC suggest that it is better to focus on the 
social, contextual, and organizational factors in explaining the 'who, what, and when' of entrepreneurship?

It is important to acknowledge that many of the resources utilized by Jack in starting TWC were supplied by his former firm, Cooley Distillery, and that Jack accumulated a wealth of experience, knowledge, and networks in Cooley that allowed him to establish and run TWC. Based on this case, there is substantial evidence that some entrepreneurs are 'nurtured'. We can acknowledge that Jack possesses the well-recognized characteristics of an entrepreneur, some of those being: determination, confidence, risk-taking, and realism. However it can be argued that these characteristics were fostered and developed through the educational, professional, and family environments Jack was exposed to.

On the other hand, there is a case for the 'nature' explanation of entrepreneurship. Shane (2010) argues that genetics have a substantial part to play in a person's potential to be an entrepreneur: 'A long line of research shows that personality influences whether people are leaders or followers, whether they like sedentary or active jobs, and even whether they are satisfied or unhappy with their jobs'(Shane, 2010). Given the fact that Jack's father is a serial entrepreneur, there was an increased likelihood that Jack was 'genetically' predisposed to possessing an entrepreneurial nature. However, it is difficult to know if Jack would have left his successful career at Cooley and established TWC purely based on innate entrepreneurial qualities. Did he need the experiences, knowledge and education he acquired and the push of the sale of Cooley to begin his entrepreneurial career?

Jack believes entrepreneurship is a combined result of nature and nurture. Jack knew his independent personality was not suited to a role in which he would be micromanaged. He found managing his own business to be a more appealing offer than staying in Cooley where he would be subject to the controls common in multinational businesses. His propensity for 
risk taking was one that he developed from his professional experiences, both in Cooley and in other companies.

\section{Potential Audience and Suggested Teaching Approach}

The primary aim of this case study is to highlight the importance of an entrepreneur's prior knowledge on the success of the venture creation process. This case is of particular relevance to beginning-level undergraduate students due to the distinct examples of entrepreneurial thought and action presented throughout. By drawing on the Timmons Model of the Entrepreneurial Process (Spinelli and Adams, 2012) students can examine the case in relation to the three critical elements to entrepreneurial success: opportunity evaluation, resource assembly, and team creation. The case raises good conversation points which are conducive to open discussion in class. A secondary aim of this teaching case is to ignite students' interest in entrepreneurship, particularly in the context of family business.

We suggest the following teaching approach.

- The tutor/ lecturer/facilitator provides an introduction to the issues present in the case. Issues include enterprise start-up, pre-incubation, family business, and resource gathering. If the class is two hours, we suggest the first hour is dedicated to covering one or two of these topics.

- In preparation for the class, students should review the case study. It is also recommended that students (of the legal age for alcohol consumption) visit the TWC website (teelingwhiskey.com), the TWC Facebook and Twitter pages (facebook.com/TeelingWhiskeyCompany and twitter.com/teelingwhiskey), and watch the short videos posted on the TWC Vimeo page (vimeo.com/teelingwhiskey). In class, students can comment on the effectiveness of TWC's social media presence in terms of relevance to target audience, user friendliness, and interactivity. Then split 
students into equal groupings to critique the case in terms of Jack's ability to perceive opportunities, gather resources, and assemble a team. An open discussion should ensue. Further questions to stimulate debate include:

Was Jack right to leave Cooley Distillery and pursue his own entrepreneurial venture?

Is Jack's entrepreneurial orientation a result of nurture or nature?

Is industry knowledge and experience enough to make a venture work?

\section{Suggested reading}

Audia, P.G., and Rider, C.I. (2005), 'A garage and an idea: what more does an entrepreneur need?'. California Management Review, Vol 48, No 1, pp 6-28.

Freeman, J. (1986), 'Entrepreneurs as organizational products: semiconductor firms and venture capital firms', Advances in the study of entrepreneurship, innovation, and economic growth, Vol 1, pp 33-52.

Shane, S. (2000), 'Prior knowledge and the discovery of entrepreneurial opportunities', Organization Science, Vol 11, No 4, pp 448-469.

\footnotetext{
Note

${ }^{1}$ Poitin is an age old Irish spirit that was outlawed in 1600's Ireland due to its potency. It was legalized for consumption by the Irish government in 1997.
} 


\section{References}

Bodkin, P. (2015), 'Inside the first whiskey distillery to open in Dublin in over 125 years', The Journal [online], 8 June. Available from: http://businessetc.thejournal.ie/teelingwhiskey-distillery-2-2115395-Jun2015/

Carvalho, L., and Williams, B., (2014), 'Let the cork fly: creativity and innovation in a family business', International Journal of Entrepreneurship and Innovation, Vol 15, No 2, pp 127-133.

Fiet, J.O. (1996), 'The informational basis of entrepreneurial discovery', Small Business Economics, Vol 8, No 6, pp 419-430.

Freeman, J. (1986), 'Entrepreneurs as organizational products: semiconductor firms and venture capital firms', Advances in the study of entrepreneurship, innovation, and economic growth, Vol 1, pp 33-52.

Irish Whiskey Act, 1980. Act number 33 of 1980, s.1 [Online]. Available from: http://www.irishstatutebook.ie/1980/en/act/pub/0033/print.html.

Schumpeter, J.A. (1934), The Theory of Economic Development: An Inquiry Into Profits, Capital, Credit, Interest and the Business Cycle, Vol. 55, Transaction Publishers, New Brunswick.

Shackle, G.L.S. (1979), Imagination and the Nature of Choice, Edinburgh University Press, Edinburgh.

Shane, S. (2000), 'Prior knowledge and the discovery of entrepreneurial opportunities', Organization Science, Vol 11, No 4, pp 448-469.

Shane, S. (2010), Born Entrepreneurs, Born Leaders: How Your Genes Affect Your Work Life, Oxford University Press, UK. 
Shanken News Daily (2014). Hitting US next month, Teeling aims to fill Irish whiskey's super-premium gap. Shanken News Daily [Online], 6 March. Available from: http://www.shankennewsdaily.com

Spinelli, S., and Adams, R. (2012), New Venture Creation-Entrepreneurship for the 21st Century $\left(9^{\text {th }}\right.$ ed.) McGraw-Hill/Irwin, New York.

Teeling Whiskey Company (2014). Teeling whiskeys honoured as world's best, [Press Release], 6 June. Available from: http://teelingwhiskey.com/2014/06/teelingwhiskeys-honoured-as-worlds-best/\#.VJIVG14gH8

Venkataraman, S. (1997), 'The distinctive domain of entrepreneurship research: an editor's perspective', in Katz, J., and Brockhaus, R., eds, Advances in Entrepreneurship, Firm Emergence and Growth, Vol 3, pp 119-138. JAI Press, Greenwich, CT. 